\title{
Global Adjustments to a Shrinking U.S. Trade Deficit
}

SinCE EARLY 1985, when the U.S. administration began to encourage the depreciation of the dollar to reduce the U.S. trade imbalance, there has been considerable discussion of the need for international policy coordination to bring about a "soft landing" in the world economy. Two kinds of recessionary risks have been widely discussed. The first is that the United States will do little about its budget deficit, so that foreigners will be called on to provide significant financing for many years to come. If they become reluctant to lend, then U.S. interest rates could soar, causing the dollar to collapse, and pushing the United States into a recessionary balance-of-payments crisis.

The second recessionary risk starts from an almost opposite premise: that the United States will cut its budget deficit sharply, without a compensatory fiscal expansion abroad, and thereby throw the world into an aggregate demand slump. U.S. Treasury officials in the past three years have strongly urged more expansionary fiscal policies in Germany and Japan to avoid this outcome, and influential independent economists have concurred in this advice.

This paper examines the prospects for reducing the U.S. trade imbalance and the plausibility of the hard-landing scenarios. A review of evidence on the sources of the trade deficit finds that the U.S. budget deficit is the most important, but not the only major, source. Reducing the budget deficit would help to reduce the trade deficit, but even if the

This paper has benefited substantially from a collaborative research effort on simulation modeling of international macroeconomic interdependence with Warwick McKibbin of the Reserve Bank of Australia. The global simulation project is supported by grants from the World Institute of Development Economics Research (WIDER), in Helsinki, Finland, and from the Brookings Institution. 
budget deficit were eliminated, a substantial trade deficit would remain. Equally important, an attempt to reduce the trade deficit further by a depreciating exchange rate induced by easier monetary policy would, at this stage, produce inflation with little benefit on the current account.

A second finding is that a hard landing caused by a withdrawal of investor confidence is implausible in the next few years, though certainly not impossible. The experience of the Latin American economies in the 1980s is proof enough that a crisis based on a loss of foreign confidence can indeed occur, but attempts to draw close analogies between the U.S. situation and that of Latin America are unconvincing. Furthermore, there is, at least as yet, little evidence of a rising risk premium on dollar assets. The evidence to date is that, for good or bad, the U.S. deficits can be financed abroad for some time yet without triggering steeply rising interest costs.

The third finding of the paper is that the global recessionary risks of fiscal tightening in the United States are overblown. Simulation exercises suggest that U.S. fiscal tightening need not be balanced by fiscal expansions abroad. Even though a U.S. fiscal contraction would tend to reduce the demand for European and Japanese exports, it would also reduce world interest rates, thereby spurring internal demand in Europe and Japan. On balance, the effects of U.S. budget cutting may well be expansionary on the rest of the world, and can almost surely be made so with accommodating monetary policy abroad. Indeed, the current " miniboom" in Germany and Japan, in which growth during 1987-88 has been significantly higher than anticipated, would appear to show this mechanism at work.

\section{Origins of the U.S. Trade Imbalance}

General public opinion makes the fundamental mistake of viewing trade imbalances as a reflection of trade policies and trade distortions, rather than as a reflection of saving and investment behavior usually unrelated to trade policies. While there may be cases in which a change in trade policies can affect the trade balance (through indirect effects on saving and investment behavior), there is little reason to believe that growing trade or current account imbalances in the industrialized countries since the early 1980s have had anything to do with changes in trade policies in this decade. 
Table 1. Current Account Imbalances, Industrial Economies, 1985-88

\begin{tabular}{|c|c|c|c|c|c|c|c|c|}
\hline \multirow[b]{2}{*}{ Economy } & \multicolumn{2}{|c|}{1985} & \multicolumn{2}{|c|}{1986} & \multicolumn{2}{|c|}{1987} & \multicolumn{2}{|c|}{$1988^{\mathrm{a}}$} \\
\hline & $\begin{array}{l}\text { Billions } \\
\text { of dollars }\end{array}$ & $\begin{array}{l}\text { Percent } \\
\text { of } G N P\end{array}$ & $\begin{array}{l}\text { Billions } \\
\text { of dollars }\end{array}$ & $\begin{array}{l}\text { Percent } \\
\text { of } G N P\end{array}$ & $\begin{array}{l}\text { Billions } \\
\text { of dollars }\end{array}$ & $\begin{array}{l}\text { Percent } \\
\text { of } G N P\end{array}$ & $\begin{array}{l}\text { Billions } \\
\text { of dollars }\end{array}$ & $\begin{array}{l}\text { Percent } \\
\text { of GNP }\end{array}$ \\
\hline United States & -116.5 & -2.9 & -141.3 & -3.3 & -160.7 & -3.6 & -150 & -3.1 \\
\hline Japan & 49.2 & 3.7 & 85.8 & 4.4 & 87.0 & 3.6 & 85 & 2.9 \\
\hline Germany & 16.2 & 2.6 & 37.9 & 4.2 & 44.3 & 3.9 & 47 & 3.8 \\
\hline G-7 countries ${ }^{b}$ & -51.7 & -0.7 & -18.4 & -0.2 & -44.6 & -0.4 & -44 & -0.4 \\
\hline Smaller European & & & & & & & & \\
\hline countries $^{\mathrm{b}}$ & 7.6 & 0.8 & 7.3 & 0.6 & 1.1 & 0.1 & -5 & -0.3 \\
\hline Total OECD & -54.1 & -0.6 & -22.3 & -0.2 & -53.5 & -0.4 & -58 & -0.4 \\
\hline
\end{tabular}

Source: OECD Economic Outlook, no. 43 (June 1988), pp. 57-58, tables 28, 29, and 30.

a. Projections.

b. OECD reports country data as a percent of GNP or GDP depending upon conventional measurement within each country.

As ample research has stressed, three macroeconomic developments adequately account for the bulk of the current account imbalances shown in table 1. The first is the divergence of fiscal policies in the Organization for Economic Cooperation and Development economies, primarily the growth of U.S. fiscal deficits and the reduction of fiscal deficits in Germany and Japan; the second is the liberalization of international capital flows in several countries, especially Japan, in the early 1980s; and the third is the cutoff in lending to the debtor developing countries, which forced a reduction in the trade deficits in the debtor countries, and thereby resulted in greater trade deficits in the rest of the world.

Nuriel Roubini and I used a multicountry simulation model to make a rough assessment of the quantitative role of these factors in accounting for the changes in trade imbalances in the United States and Japan between 1978 and $1985 . .^{1}$ The effects of the U.S. trade balance, the Japanese trade balance, and the yen-dollar real exchange rate are shown in table 2. For each variable, the actual change shown records the 1985 value relative to its average value during 1978-80. Between 1979 and 1985, OECD estimates of the U.S. inflation-adjusted structural budget deficit increased by 4.4 percent of U.S. GNP; the Japanese full-employment budget deficit decreased by 3.7 percent of GNP; and the fullemployment budget deficit in the rest of the OECD decreased by 0.5 percent of GNP. External net lending to the nonoil developing countries

1. Jeffrey D. Sachs and Nuriel Roubini, "Sources of Macroeconomic Imbalances in the World Economy: A Simulation Approach," Working Paper 2339 (National Bureau of Economic Research, August 1987). 
Table 2. Decomposition of Changes in the External Balance and Bilateral Exchange Rate, United States and Japan, 1978-80 through 1985

Percent

\begin{tabular}{|c|c|c|c|c|c|c|c|}
\hline \multirow[b]{3}{*}{ Variable } & \multirow[b]{3}{*}{$\begin{array}{l}\text { Actual } \\
\text { change }\end{array}$} & \multirow[b]{3}{*}{$\begin{array}{l}\text { Predicted } \\
\text { change }^{\mathrm{b}}\end{array}$} & \multicolumn{5}{|c|}{ Decomposition of predicted change } \\
\hline & & & \multicolumn{3}{|c|}{ Fiscal policies } & \multirow[b]{2}{*}{$\begin{array}{l}L D C \\
\text { lending }\end{array}$} & \multirow[b]{2}{*}{$\begin{array}{l}\text { Monetary } \\
\text { policies }\end{array}$} \\
\hline & & & $\begin{array}{l}\text { United } \\
\text { States }\end{array}$ & Japan & $\begin{array}{l}\text { Rest of } \\
\text { OECD }\end{array}$ & & \\
\hline U.S. trade balance ${ }^{c}$ & -1.9 & -1.8 & -1.0 & -0.2 & -0.0 & -0.4 & -0.2 \\
\hline Japanese trade balance ${ }^{c}$ & 3.2 & 2.8 & 1.4 & 1.9 & -0.1 & -0.6 & 0.3 \\
\hline $\begin{array}{l}\text { U.S.-Japan real exchange } \\
\text { rate }^{\text {d }}\end{array}$ & ge 24.0 & 28.0 & 11.8 & 10.6 & -0.0 & -0.1 & 6.6 \\
\hline
\end{tabular}

Source: Jeffrey D. Sachs and Nuriel Roubini, "Sources of Macroeconomic Imbalances in the World Economy: A Simulation Approach," Working Paper 2339 (National Bureau of Economic Research, August 1987). Original data from OECD National Income Accounts.

a. The actual changes measure the 1985 value of the variable compared with the average value of the variable during 1978-80.

b. The predicted changes come from a simulation of the McKibbin-Sachs model (2), described in the source, based on changes in fiscal policies in the United States, Japan, and the rest of the OECD of the historically observed magnitudes; an exogenous reduction in lending to the LDCs; and offsetting monetary policies in the industrial countries.

c. The trade balance is measured as a percentage of GNP.

d. The real exchange rate measures the percentage change in the relative consumer price indexes of the United States and Japan, corrected for changes in the nominal exchange rate. The positive value signifies a real appreciation of the U.S. dollar.

dropped, after 1982, by approximately 1.4 percent of U.S. GNP, a development that is taken to be exogenous in the simulation exercise.

We see from the table that the U.S. trade balance worsened by 1.9 percent of U.S. GNP during this period, while the model predicts a deterioration of 1.8 percent of GNP based on the four changes just mentioned. Just over half the change in the U.S. external position (1.0 percent of GNP) is attributed to the growth in the U.S. fiscal deficit; another 0.2 percent is attributed to the Japanese fiscal contraction; and another 0.4 percent of GNP to the LDC lending cutoff. Finally, another 0.2 percent is ascribed to the combined effects of monetary policy changes in each of the regions in the model. ${ }^{2}$ In the case of the Japanese trade surplus, which rises by 3.2 percent of GNP, the model predicts an

2. The underlying monetary policy assumed in the simulation exercise is that monetary policy leans against fiscal policy to keep an overall macroeconomic balance. In the United States, tight monetary policy during $1978-85$ balances the expansionary fiscal policy; in Japan and the rest of the OECD, loose monetary policy balances the effects of the tight fiscal policy. In any event, monetary policy has little effect on the external balance, a point to which I shall return, though monetary policy has an important effect on the level of internal economic activity and on the overall level of exports and imports (but not on exports minus imports). 
improvement of 2.8 percent based on the fiscal and monetary policy changes, of which 1.9 percent is ascribed to the Japanese fiscal contraction, and 1.4 percent to the U.S. fiscal expansion.

Capital market liberalization, especially in Japan after 1980, comes into these estimates indirectly. Without the liberalization of Japanese capital movements, the Japanese trade imbalances would not have been sustained. The Japanese fiscal contraction for the same period, for example, would have reduced domestic interest rates in Japan, thereby inducing an increase in Japanese domestic investment (and perhaps a fall in private saving), rather than a capital outflow and a trade surplus. The yen would not have experienced its 24 percent real depreciation between $1978-80$ and 1985 .

The estimates in table 2 examine the changes in external balances between 1978-80 and 1985. Between 1985 and 1988, the U.S. external balance turned even more negative (fairly sharply in 1986 and 1987, before improving slightly in 1988). It would seem that these subsequent changes cannot be well explained by fiscal policy changes after 1985 , since the U.S. budget deficit has declined as a percentage of GNP while the external deficit has grown. As in the first half of the 1980s, there is no evidence that shifts in trade policy, either actual or anticipated, in the United States or abroad played a role. As an accounting matter, the current account deficit (equal to national investment minus national saving) deteriorated further because private saving, mainly household saving, fell sharply, even as public saving increased (that is, became less negative). The household saving rate fell from an average of 6.8 percent of disposable income during 1980-84 to 3.9 percent of disposable income in $1987 .{ }^{3}$

Some of the decline in the private saving rate might be an endogenous response to macroeconomic policy. For example, private saving might have declined to some extent because of the fall in interest rates and rising stock market values after 1985, which in turn resulted in part from expansionary monetary policy and tightening fiscal policy. It seems, however, that much of the decline cannot easily be accounted for in these terms. ${ }^{4}$ In any event, this fall in private saving rates seems to have

3. Data are from OECD Economic Outlook, no. 43 (June 1988), table R12, p. 181.

4. See Lawrence Summers and Chris Carroll, "Why Is U.S. Saving So Low?" BPEA, $2: 1987$, pp. $607-45$, for a detailed description of the puzzling decline in private saving, as well as the general inability of standard explanations to account for it. 
contributed to the recent deterioration of the external balance above and beyond the contribution of the budget deficit.

\section{Budget Deficit Reductions and the External Balance}

The data in table 3 provide further general evidence that fiscal policy changes have been important, but not one-for-one, determinants of the shifts in external imbalances since the late 1970s. Countries with growing budget deficits after 1979 experienced, on average, larger current account deficits. Since the current account equals national saving minus national investment, which in turn equals the financial balance of the government (government saving minus government investment) plus the financial balance of the private sector (private saving minus private investment), changes in the government financial imbalance will translate into current account changes if the private saving-investment balance remains unchanged. In general, the private balance will respond partially to offset changes in the public sector balance, but in general the offset will be less than complete. ${ }^{5}$

A simple regression of the change in the current account position on the change in fiscal balance, using the data of table 3, suggests that a budget deficit increase of 1.0 percent of GNP was associated, on average, with a deterioration of the current account of 0.66 percent of GNP. With $C A$ the current account surplus (and $-C A$ the deficit), and $D$ the financial deficit of the public sector, we have

$$
\begin{aligned}
d(-C A / G N P)= & 0.72+0.66 d(D / G N P), \\
& (1.15) \quad(2.91) \\
& R^{2}=0.55,
\end{aligned}
$$

with $d(-C A / G N P)$ and $d(D / G N P)$ referring to the changes of the variables for the average of 1985-86 relative to the average of 1978-79. While the offset coefficient of 0.66 should not be taken as a structural

5. Of course, in the theory of Ricardian-Barro equivalence, some kinds of changes in the public sector balance are predicted to lead to exactly offsetting changes in the private sector balance. For example, a cut in current taxes that leads to larger current budget deficits and higher future taxes is hypothesized to increase private saving as households anticipate larger future tax liabilities. In effect, households fully save, rather than spend, the increased income resulting from the tax cut, in anticipation of their future tax liabilities. 
Table 3. Changes in General Government Financial Balances and Current Account Imbalances, Industrial Countries, 1978-86 ${ }^{\mathrm{a}}$

Percent of GNP

\begin{tabular}{lcc}
\hline Country & $\begin{array}{c}\text { Change in } \\
\text { government } \\
\text { financial } \\
\text { balance }\end{array}$ & $\begin{array}{c}\text { Change in } \\
\text { current } \\
\text { account }\end{array}$ \\
\hline United States & -3.65 & -2.75 \\
Japan & 4.15 & 3.65 \\
Germany & 1.32 & 3.05 \\
France & -1.60 & -0.97 \\
United Kingdom & 0.95 & 0.30 \\
Italy & -1.90 & -2.00 \\
Canada & -3.70 & 0.85 \\
\hline
\end{tabular}

Source: OECD Economic Outlook, no. 43, tables 30, R13, and R20, pp. 58, 182, 189.

a. The change in the government financial balance measures the change in the ratio of the general government financial balance as a percentage of GNP or GDP. The change is calculated as the average value of the ratio for the years 1985-86, minus the average value for 1978-79. The change in the current account is measured similarly.

estimate (especially since the offset is likely to differ across countries), the equation clearly highlights the statistical correlation between shifts in budget policy and shifts in the external balance in the past decade.

In the simulation model underlying table 2 , a sustained, bond-financed U.S. fiscal expansion (an increase in federal spending on goods and services) worsens the U.S. trade balance in the year of the expansion by 0.34 percent of GNP and by an average of 0.31 percent of GNP over three years, with a third-year effect of 0.29 percent of GNP. Large-scale macroeconometric models give diverse estimates of the offset in the case of the United States, but the estimate of 0.31 is in the middle of the range. Table 4 shows the estimated effects of a fiscal expansion in four popular models of international macroeconomic interdependence. The thirdyear effect ranges from 0.51 percent of GNP to 0.29 percent, with an unweighted average effect of 0.40 percent of GNP. While these estimates have a moderate dispersion (and reflect the professional uncertainties on this subject), they all show a trade-off of about 0.5 or less.

Thus, the fall in public saving is matched by a rise in private saving, with no overall change in the current account balance. I do not adopt this view, consistent with a considerable body of negative theoretical and empirical evidence. For a critical survey of the theory, see B. Douglas Burnheim, "Ricardian Equivalence: An Evaluation of Theory and Evidence," in Stanley Fischer, ed., NBER Macroeconomics Annual, 1987 (MIT Press, 1987). 
Table 4. Simulations of Effect of U.S. Fiscal Expansion on U.S. Current Account ${ }^{\mathrm{a}}$ Percent of GNP

\begin{tabular}{lcc}
\hline & \multicolumn{2}{c}{ Year } \\
\cline { 3 - 3 } Model & \multicolumn{1}{c}{3} \\
\hline Japanese Economic Planning Agency & & \\
$\quad$ World Model & -0.08 & -0.40 \\
Federal Reserve Multicountry Model & -0.37 & -0.51 \\
Organization for Economic Cooperation & & \\
$\quad$ and Development Interlink & -0.37 & -0.39 \\
McKibbin-Sachs Global Model (2) & -0.34 & -0.29 \\
\hline
\end{tabular}

Source: For the first three models, John F. Helliwell, "The Effects of Fiscal Policy on International Imbalances: Japan and the United States," Working Paper 2650 (National Bureau of Economic Research, July 1988, table 4); for the McKibbin-Sachs Global Model (2), Sachs and Roubini, "Sources of Macroeconomic Imbalances in the World Economy."

a. The table measures the effect of a 1 percent of GNP increase in fiscal expenditure on goods and services, on the current account as a percent of GNP. (In the case of the McKibbin-Sachs model, the effect is measured for the trade balance rather than the current account balance.)

There are several reasons for the less than one-for-one link between changes in the budget deficits and changes in the trade balance. ${ }^{6}$ Basically, a tightening of fiscal policy (taken here to be a cut in government spending with unchanged tax policy, and thus lower bondfinanced budget deficits) induces a rise in private investment rates and a fall in private saving rates. Private investment increases as lower budget deficits lead to a reduction of interest rates and a crowding-in of investment. Private saving rates fall for cyclical reasons. The decline in government spending also leads to a temporary decline in national income (relative to a baseline path). Since households perceive the output decline as temporary, they temporarily reduce their rate of saving in response to the reduction of output, in order to smooth the path of consumption. Overall, therefore, the effect of higher government saving on the current account is partially offset by a fall in private saving and a rise in private investment.

The fairly modest effect of fiscal policy on the current account deficit has an important implication consistent with the findings of table 2 . The U.S. fiscal expansion was only one of the reasons for the widening of

6. Of course, the observed linkages between budget deficits and the trade balance will depend on the precise nature of the fiscal policy changes that are undertaken. For example, the effect of changes in bond-financed government spending on the trade balance will depend on whether the spending changes are perceived to be temporary or permanent, since the expected duration of the change will affect how households perceive the change in their own lifetime budget constraints in light of the fiscal policy measures. 
the U.S. current account deficit. Completely eliminating the U.S. budget deficit, other things being equal, would remove no more than half the current external gap. During 1987:2-1988:2 the current account deficit was 3.6 percent of GNP; the fiscal deficit, 3.4 percent of GNP. Applying a coefficient of 0.40 (the average of the four models reported in table 4) to the effect of the budget deficit on the current account deficit means that closing the budget deficit would reduce the external deficit from 3.6 percent of GNP to approximately 2.2 percent of GNP, or to about $\$ 100$ billion in 1988.

Balancing the U.S. current account will therefore require policy actions or other economic events (for example, a strong recovery of household saving) beyond balancing the U.S. budget. Fiscal policies in other countries are unlikely to make a big difference. The effects of foreign fiscal actions on the U.S. external balance are small (as table 2 shows, a 3.7 percent fiscal contraction in Japan between 1978 and 1985 worsened the predicted U.S. current account deficit by only 0.2 percent of GNP). Moreover, the fiscal contractions in Germany and Japan during the 1980s are unlikely to be reversed. The initial fiscal conditions in Germany and Japan at the end of the 1970s were at the time widely regarded as having been undesirable and unsustainable, and there is little interest now in returning to those larger deficits. ${ }^{7}$

In conclusion, while the U.S. budget deficit is a central factor in the large current account deficit, even its complete elimination, however unlikely, would not by itself restore external balance in the United States. At the core, the U.S. external imbalance is a structural feature of the U.S. economy also reflecting the extraordinarily low net saving rate in the private sector, and particularly in the household sector, combined with sufficiently favorable investment prospects to induce a continuing inflow of foreign capital.

\section{The Exchange Rate and the External Deficit}

So far I have focused on the saving-investment balance in interpreting the U.S. current account imbalance, attributing the external deficit to

7. In Japan, the general government financial balance in 1979 was a deficit of 4.7 percent of GNP (significantly larger than the current U.S. budget deficit), and the German deficit was 2.5 percent of GNP. In both countries, the ratio of public net debt to GNP had risen sharply in the late 1970 s, to the considerable concern of policymakers in both countries. See OECD Economic Outlook, no. 43 (June 1988), table R13. 
the low saving rate, which in turn results from large budget deficits combined with a chronically low and declining private saving rate. How does this interpretation square with the conventional view that it was the strong dollar during 1980-85 that caused the large trade deficits, and that a weak dollar now will make the trade deficit disappear?

The answer is that the dollar exchange rate is an endogenous variable and therefore cannot be considered a cause of movements in the trade balance. As shown later, the dollar appreciated in the early 1980 s because of high U.S. interest rates, which were in turn caused by the large U.S. fiscal deficits coupled with tight monetary policy. ${ }^{8}$ It was the monetaryfiscal mix that was behind both the appreciation of the dollar and the rising external deficits. Similarly, a change in policy mix since 1985 (easier money, combined with some actual and some anticipated tightening of fiscal policy) can explain much of the subsequent depreciation of the dollar.

Stressing the more fundamental role of fiscal policy for the movement both of the exchange rate and of external balance helps avoid one fallacy common in policy discussion. It is sometimes suggested that the United States needs only a further fall of the dollar to balance its external accounts; how that decline in the dollar is to be brought about is left unspecified. But the source of the dollar decline is crucial in assessing how it would affect the development of the trade balance. To the extent that the dollar depreciates because of tighter fiscal policy, the effect would be a further improvement in the trade balance (on the order of 0.4 times the change in fiscal policy). By contrast, to the extent that the dollar depreciation is induced by a monetary expansion, the benefits for the trade balance would be much smaller, and perhaps nonexistent.

Consider what happens to the trade balance if the Federal Reserve eases monetary policy to drive the dollar lower. A monetary expansion causes the domestic interest rate to decline and induces an incipient capital outflow, causing the dollar to depreciate. The weaker dollar boosts exports and thereby GNP (assuming initial excess capacity), which in turn causes national saving to rise (since household consumption

8. A fiscal expansion induces a dollar appreciation by causing domestic interest rates to rise, thereby inducing an incipient capital inflow, as wealthholders attempt to shift out of foreign assets to buy higher-yield domestic assets. The dollar then appreciates until the point where the interest rate differential between the United States and abroad is just balanced by an expected future depreciation of the dollar. 
Table 5. Simulations of Effects of U.S. Monetary Expansion on the Effective U.S. Exchange Rate and U.S. Current Account ${ }^{\mathrm{a}}$

\begin{tabular}{|c|c|c|c|c|}
\hline \multirow[t]{3}{*}{ Model } & \multicolumn{2}{|c|}{$\begin{array}{l}\text { Current account } \\
\text { (change as } \\
\text { percent of GNP) }\end{array}$} & \multicolumn{2}{|c|}{$\begin{array}{c}\text { Nominal } \\
\text { exchange rate } \\
\text { (percent change) }\end{array}$} \\
\hline & \multicolumn{2}{|c|}{ Year } & \multicolumn{2}{|c|}{ Year } \\
\hline & 1 & 3 & 1 & 3 \\
\hline \multicolumn{5}{|l|}{ Japanese Economic Planning Agency } \\
\hline World Model & -0.02 & 0.02 & -1.0 & -1.7 \\
\hline Federal Reserve Multicountry Model & -0.03 & -0.01 & -1.7 & -1.5 \\
\hline $\begin{array}{l}\text { Organization for Economic Cooperation } \\
\text { and Development Interlink }\end{array}$ & -0.11 & 0.01 & -0.9 & -0.6 \\
\hline McKibbin-Sachs Global Model (2) & -0.00 & 0.01 & -1.4 & -1.1 \\
\hline
\end{tabular}

Source: For the first three models, see Ralph C. Bryant and others, "Estimates of the Consequences of Policy Actions," in Ralph C. Bryant and others, eds., Empirical Macroeconomics for Interdependent Economies (Brookings, 1988), tables 4-15 and 4-16, pp. 78-79. The original data for the current account record the change in absolute billions of dollars, rather than as a percent of GNP. The conversion is made using a baseline value of GNP of $\$ 3,900$ billion (1985 value) for year 1 , and $\$ 4,400$ billion for year 3. For the McKibbin-Sachs Global Model (2), see Sachs and Roubini, "Sources of Macroeconomic Imbalances in the World Economy," table 7. (The nominal exchange rate must be calculated from the table, using the reported values of the real exchange rate and the inflation rate.)

a. The table records the effect of a permanent 1 percent increase in the U.S. money supply (M1) on the current account (change as percent of baseline GNP) and on the exchange rate (percent change).

b. Negative sign signifies depreciation.

will rise less than the temporary, money-induced increase in output). At the same time, the lower domestic interest rates will cause domestic investment to rise.

Because the external balance will change according to the rise of saving minus the rise of investment, a weaker dollar brought about by a monetary expansion has an ambiguous effect on the trade balance. Both saving and investment tend to rise, and the trade balance may either improve or worsen. Put in more conventional terms, the weaker dollar resulting from the monetary expansion induces a rise in exports, but it also causes a rise in imports, since domestic spending is increased by lower domestic interest rates.

Table 5 reports the effects of money expansion on the exchange rate and trade balance in the same simulation models reported in table 4 . The point of this section is strongly borne out: while a monetary expansion is predicted to lead to a dollar depreciation in each of the models, the effect on the trade balance is generally small, and actually negative in the first year, and of ambiguous sign in the third year. In the Multicountry Model of the Federal Reserve Board Staff, the dollar depreciation is associated with a worsening in the current account balance by the third 
year, while in other models it is associated with an improvement. The overall message is crucial, but not widely understood. Driving down the dollar through a low-interest monetary policy improves the trade balance little, if at all.

As I will point out later, much of the decline in the dollar since 1985 has resulted from a combination of easy monetary policy and the expectation of tighter fiscal policy, rather than from an actual tightening of fiscal policy. This point helps to explain why the improvement in the external trade balance has been so modest, despite the sharp depreciation of the dollar.

The U.S. current account deficit has declined from approximately 3.3 percent of GNP in 1986 to an estimated 3.1 percent of GNP in 1988. The part of the depreciation due to monetary expansion has led to rapid growth, but little improvement in the trade balance. The part due to an actual cut in the fiscal deficit has been small. With the fiscal deficit having declined by about 1.5 percent of GNP between 1986 and 1988, the estimated trade balance effect is predicted to be only about $0.4 \times 1.5$ percent of GNP, or about 0.6 percent of GNP, or slightly larger than the current account gains to date.

\section{Will Foreign Investors Close the External Deficit?}

One theme of the hard-landing school is that if the U.S. fiscal authorities do not close the budget deficit sufficiently to balance the external deficit, the external creditors of the United States will close the external deficit for us, by reducing the inflow of foreign capital. ${ }^{9}$ The concern is that such a cutoff in lending would likely be disorderly, causing a large jump in interest rates and a sharp fall of the dollar, thereby provoking a recession in the United States, combined with a jump in inflation following the collapse of the currency. Many commentators in the past two years have viewed the steep depreciation of the dollar that has already occurred as the first manifestation of the feared hard landing.

9. This risk has been stressed by Stephen Marris, Deficits and the Dollar: The World Economy at Risk, Policy Analyses in International Economics no. 14 (Washington, D.C.: Institute for International Economics, 1985); and by Martin Feldstein, "The Stock Market Decline and Economic Policy," testimony to the Banking Committee of the U.S. House of Representatives, October 29, 1987. 
But while the theoretical possibility of this kind of crisis clearly exists, a quantitative assessment of the risks shows that such fears are exaggerated, at least for the next few years.

The theoretical case is straightforward. A current account deficit depends on the availability of foreign financing. With a zero net capital inflow, no external current account deficit is possible. In the event that foreign creditors stop lending to U.S. residents, the U.S. residents can continue to run current account deficits only so long as they can run down accumulated gross assets-assets held abroad and official foreign exchange reserves. Eventually, as the gross asset stock is reduced, the current account must come into balance, and even move into surplus if an amortization of foreign liabilities is required by the foreign creditors (and if there is no default on these obligations).

Assuming that the budget deficit remains large, the cutoff in foreign lending leads to a sharp increase in domestic interest rates, until the private net financial position $\left(S^{P}-I^{P}\right)$ rises sufficiently, through lower investment spending and higher saving, to finance the budget deficit entirely out of surplus private domestic funds. The cutoff in foreign funds thereby converts the effect of the budget deficit from one of external crowding out (deterioration of the current account deficit) to the traditional closed-economy case of internal crowding out of investment.

At the moment that the foreign inflow ceases, there is a steep drop in demand for domestic goods and a sharp real dollar depreciation, in the sense both of a reduction in the price of domestic goods relative to foreign goods and of a reduction in the price of nontradable goods relative to tradable goods. It is likely that the collapse in internal demand caused by the rise in domestic interest rates will lead to unemployment. Workers laid off by the declining nontradables sector are unlikely to be absorbed instantly into export and import-competing sectors. ${ }^{10}$ Part of the adjustment mechanism of the sudden balancing of the current account,

10. There are several reasons why the adjustment process is likely to result in a transitional period of (perhaps high) unemployment. The sudden drop in internal demand requires a reallocation of resources from nontradables production to tradables production. This resource reallocation generally requires a fairly sharp drop in real wages to induce the tradables sector firms to hire the labor laid off by the nontradables sector. Assuming any form of real wage resistance (or nominal wage rigidity combined with a monetary authority resisting internal inflation), the result will be a rise in unemployment. 
therefore, is likely to be a steep drop in domestic output and a rise in unemployment.

The case of Mexico in 1982-83 is a classic example of a hard landing. (Almost any Latin American country in the 1980s would serve the purposes of illustration.) During 1979-82, the Mexican government ran enormous budget deficits, reaching 14 percent of GDP in 1981, on the eve of the crisis. ${ }^{11}$ These deficits contributed to large current account deficits of more than 5 percent of GDP in 1981. Through the combination of a steep rise in world interest rates, weakening oil prices, and growing skepticism over Mexican fiscal management, private foreign investment shifted remarkably from a net capital inflow of medium- and long-term funds of $\$ 11.5$ billion in 1981 , to $\$ 6.1$ billion in 1982 , and only $\$ 2.7$ billion in 1983. Mexico tried to roll over existing debts in the spring of 1982, but found itself unable to attract the desired loans. It announced in the summer of 1982 that it would therefore be unable to meet its principal obligations in the short run, and that announcement in turn provoked a virtually instantaneous and complete withdrawal of new credits.

The cutoff in foreign lending had the expected effect. The current account moved from a deficit of $\$ 6.2$ billion in 1982 to a surplus of $\$ 5.3$ billion in $1983 .{ }^{12}$ The currency collapsed, inflation accelerated sharply, and Mexican GNP declined 5 percent in real terms in 1983.

\section{Is the United States Next?}

The plausibility of the hard-landing scenario is often argued on the basis of three observations. First, the U.S. fiscal and external positions are serious enough to generate profound external concern and reticence to lend. Second, even if the budget deficit is not large relative to U.S. GNP, the foreign financing required (currently $\$ 150$ billion a year) is large relative to the rest of the world. Third, the sharp fall of the dollar since its peak in 1985 shows the dwindling of the foreign appetite for dollar-denominated assets. All three arguments are dubious.

11. The data and descriptions for Mexico are based on Ed Buffie, "Economic Policy and Foreign Debt in Mexico," forthcoming in Jeffrey Sachs, ed., Developing Country Debt and Economic Performance: Country Studies (University of Chicago Press, 1989).

12. The surplus resulted from the fact that the Mexican monetary authorities accumulated foreign exchange reserves in 1983, raising them from a totally depleted level in the summer of 1982 . 
Analogies between the United States and Latin America are misleading. The U.S. situation, for example, differs significantly from that of Mexico in 1981. The Mexican current account deficit was more than 5 percent of GNP, compared with a U.S. current account deficit this year of about 3 percent of GNP. More importantly, the Mexican terms of trade were deteriorating sharply as a result of the fall of oil prices in 1982 , thereby causing a sharp deterioration of the trade balance and the budget deficit. The Mexican net-debt-to-GNP ratio (measured as gross external debt minus foreign exchange reserves) was on the order of 50 percent of GNP, compared with the U.S. net foreign investment position at the end of 1987 of around 8 percent of GNP.13

Perhaps most important, the net indebtedness of the Mexican public sector was increasing rapidly. The public sector deficit in 1981 was on the order of 14 percent of GNP, and the inflation-adjusted deficit was on the order of 11 percent of GNP, which was leading to an explosion of the ratio of public sector debt to public sector revenue. ${ }^{14}$ On the prevailing policy path of 1981-82, it was evident that the Mexican public sector could experience profound financial distress.

In the United States, on the contrary, the net indebtedness of the public sector has approximately stabilized as a percentage of GNP, and as a percentage of annual government revenues, even on a projection of

13. It is probably true, however, that standard ways of reporting the net debt positions of the United States and of Latin America overstate the differences between the regions. The Mexican net debt position reported in the text does not count the net foreign assets of the Mexican private sector that were accumulated through heavy capital flight in the late 1970s and early 1980s, while the U.S. net foreign investment position does (in principle) count the net foreign assets of U.S. residents abroad. Buffie, "Economic Policy and Foreign Debt in Mexico," makes a rough correction of this problem, by measuring Mexico's net debt as the cumulative dollar value of current account deficits for Mexico. On this alternative measure, Mexico's net international indebtedness at the end of 1982 was on the order of $\$ 52$ billion (rather than a conventional measure of net debt of around $\$ 87$ billion), or about 30 percent of GNP. There is also a long and complex debate over the accuracy of the U.S. data. On the one side, U.S. assets held abroad are probably understated (thus exaggerating the U.S. net debt position), since foreign direct investment is valued at historical cost rather than market value. On the other hand, there are surely large unreported foreign holdings of assets in the United States (thus understating the U.S. net debt position), as evidenced by the errors and omissions account of the U.S. balance of payments during the past decade.

14. The inflation-adjusted deficit measure subtracts from the conventional deficit measure the inflation component of interest payments on the internal debt. The calculation for Mexico was made by Buffie, "Economic Policy and Foreign Debt in Mexico," table 5.9 . 
continuing budget deficits of about $\$ 150$ billion a year for the next five years. According to the Congressional Budget Office outlook as of February 1988, the federal debt held by the public reached 43.0 percent of GNP in 1987 and is projected to reach 43.4 percent of GNP in 1993 under current budget policy. The reason for the stability in the ratio should be clear. With nominal GNP projected to grow about 6.5 percent a year, the nominal debt itself can grow at the same rate without an increase in the debt-GNP ratio. Since the federal debt was 43 percent of GNP in 1987 , it can grow each year by 2.8 percent of GNP $(6.5 \times 0.43)$, or about $\$ 130$ billion in 1988, without an increase in the debt-GNP ratio. Since the deficit after 1990 is projected to be somewhat less than 2.8 percent of GNP, the projected ratio of debt to GNP begins to fall very slightly after $1990 . .^{15}$

Thus, the burden of the external indebtedness of the United States, and of the public debt, is under broad control compared with the explosive situation in Mexico and many other Latin American countries in 1982. But the argument is sometimes made that even if the external and internal debt and deficits are manageable relative to U.S. GNP, the amounts of foreign financing implied by the current situation are nonetheless too large from the point of view of the world economy. Will the world continue to lend the United States $\$ 150$ billion a year without demanding a sharp increase in interest rates?

Skeptics point out that the implied capital flows are far larger, relative to the size of the world economy, than anything experienced in the past 30 years. But the historical record is misleading on this point. Until the 1980 s, capital controls were sufficiently extensive to bar a sustained capital transfer among the industrial countries. Effective controls were in place in Japan, the United Kingdom, France, Italy, and most of the smaller European countries. By 1987, most controls had been eliminated. Moreover, the European community is now committed to complete internal capital market liberalization by 1992 , which, when combined with the free international capital mobility in the largest European countries, will effectively integrate the entire European Community in the world pool of savings.

Table 6 shows the U.S. budget and current account deficits as a percentage of a conservatively estimated pool of saving and income that

15. See Congressional Budget Office, The Economic and Budget Outlook: Fiscal Years 1989-1993 (Government Printing Office, February 1988), table II-1, p. 50. 
Table 6. U.S. Budget and Current Account Deficits relative to Foreign Saving and Income, 1987

Billions of dollars except as noted

\begin{tabular}{lcc}
\hline \multicolumn{1}{c}{ Item } & $\begin{array}{c}\text { Gross national } \\
\text { saving }\end{array}$ & $\begin{array}{c}\text { Gross domestic } \\
\text { product }\end{array}$ \\
\hline Japan & 774 & 2,375 \\
European Community & 822 & 3,928 \\
Total & 1,596 & 6,303 \\
U.S. budget deficit as & & \\
$\quad$ percent of total & 9.5 & 2.4 \\
U.S. current account & & \\
as percent of total & 9.6 & 2.4 \\
\hline
\end{tabular}

Source: OECD National Income Accounts. Yen figures converted to dollars using average annual exchange rate as reported in the International Monetary Fund, International Financial Statistics.

ignores OPEC savers and includes only Japan and the European Community. In flow terms, the 1987 U.S. external deficit was 9.6 percent of the combined annual saving of Japan and the European Community. While financing the U.S. budget deficit and external deficit is not necessarily a desirable use of world savings, it would seem at least to be a feasible option.

\section{Interpreting the Decline in the Dollar}

The viewpoint just presented is optimistic about the ability of the United States to finance its external deficits in the next few years. An important competing view holds that the decline of the dollar in recent years is itself grounds for pessimism. Martin Feldstein, among others, contends that the decline of the dollar has resulted from the increasing reluctance of foreigners to hold dollar-denominated claims, which has therefore reduced the private capital inflows into the United States, causing a sharply falling dollar. ${ }^{16}$ In this interpretation, sharply rising interest rates will be needed to encourage the requisite flows of capital from abroad, unless the U.S. budget deficit is decisively cut. ${ }^{17}$ Without a sudden hard landing, as in Mexico, there will at least be a progressive reduction in domestic demand through an escalation of real interest rates.

16. Feldstein, "Stock Market Decline."

17. Marris, Deficits and the Dollar. 
To examine this argument, let us begin with a simple model of exchange rate determination. ${ }^{18}$ Let $r$ be the expected real interest rate on a defaultfree one-period dollar-denominated bond, and let $r^{*}$ be the expected real interest rate on a one-year foreign-denominated bond. Let $P$ and $P^{*}$ be the domestic and foreign price levels, and let $p$ and $p^{*}$ be the logarithms. Thus, $r=i-\left(p_{t+1}^{e}-p_{t}\right)$ and $r^{*}=i^{*}-\left(p_{t+1}^{* e}-p_{t}^{*}\right)$, where $\left(p_{t+1}^{e}-p_{t}\right)$ is the expected inflation of the domestic prices. The real exchange rate, $X$, is defined as $E P^{*} / P$, where $E$ is in units of dollars per unit of foreign currency. Let $x$ and $y$ be the logarithm of the real and nominal exchange rate, respectively. Note that a rise in $x$ is then a real depreciation of the dollar. Let $x_{n}^{e}$ be the expected value of $x$ in $n$ years.

Assuming risk-neutral foreign investors, interest arbitrage across national borders requires

$$
\left(y_{t+1}\right)^{e}=y_{t}+i_{t}-i_{t}^{*} .
$$

Using the definition of real interest rates, and the fact that $x_{t+1}-x_{t}=$ $y_{t+1}-y_{t}+\left(p_{t+1}^{*}-p_{t}^{*}\right)-\left(p_{t+1}-p_{t}\right)$, yields

$$
\left(x_{t+1}\right)^{e}=x_{t}+r_{t}-r_{t}^{*} .
$$

Summing over equation 2 for periods $t$ until $t+n$ yields

$$
\left(x_{t+n}\right)^{e}=x_{t}+n\left(r_{n}^{e}-r_{n}^{* e}\right),
$$

where $r_{n}^{e}$ is the $n$-period expected real interest rate, expressed as an annual yield, as of time $t$. To get from equation 2 to equation 3, I use the assumption of risk neutrality and rational expectations to write the $n$ period yield as the average of the expected yields on the one-period bonds between time $t$ and time $t+n \cdot{ }^{19}$

The model is completed by assuming that $n$ is large enough (say five to ten years), so that by $n$ years the real exchange rate is expected to be

18. See Jeffrey D. Sachs, “The Dollar and the Policy Mix: 1985,' BPEA, 1:1985, pp. 117-47; and Peter Hooper and Catherine Mann, "The U.S. External Deficit: Its Causes and Consequences," in The U.S. External Deficit: Causes, Consequences, and Cures, Proceedings of the twelfth annual economic policy conference, Federal Reserve Bank of St. Louis (Boston: Kluwer Academic Publishing, forthcoming, 1989).

19. Specifically,

$$
r_{n}^{e}=\frac{1}{n} \sum_{i=0}^{n-1} r_{t+1}
$$

and similarly for $r_{n}^{*}$. 
back at its equilibrium level. Suppose further that the expected equilibrium level of $x$ is a constant, $x^{c}$. For example, as Paul Krugman has recently argued on both theoretical and empirical grounds, the real exchange rate might return in the long run to a given rate based on purchasing power parity considerations. ${ }^{20}$ Then, equation 3 can be written as

$$
x_{t}=x^{c}-n\left(r_{n}^{e}-r_{n}^{* e}\right) .
$$

Now suppose that a divergent macroeconomic policy mix between the United States and the rest of the world leads to a rise in the interest rate differential of, say, 6 percentage points (as was the experience between 1978 and 1984), and say that $n$ is six years. Then, equation 4 would predict that the 6 percentage point rise in the interest differential in favor of the United States would cause a dollar appreciation of 36 percent.

This view of determinants of exchange rates therefore stresses the importance of long-term real interest rate differentials and the long-term constancy of the real exchange rate. In turn, it is macroeconomic policies (for example, the expansionary U.S. fiscal policy combined with the contractionary Japanese fiscal policy) that contribute to the shifting interest rate differential. This simple model does remarkably well in accounting for the overall movement of the dollar in the past decade, as shown in figure $1 . .^{21}$

The figure shows the real interest rate differential of the United States and a weighted average of other countries, together with the movement in the log of the real exchange rate of the dollar vis-à-vis those other currencies. ${ }^{22}$ (The figure uses $-x=p-e-p^{*}$ on the exchange rate axis, so that a rise in the index signifies a real appreciation.) The real interest rate for each country is calculated simply as the long-term rate minus the CPI inflation rate of that month over the same month the

20. See Paul Krugman, "Differences in Income Elasticities and Secular Trends in Exchange Rates," presented at the International Seminar on Macroeconomics of the National Bureau of Economic Research, in Tokyo, June 1988, and forthcoming in the European Economic Review.

21. The figure updates a diagram in Hooper and Mann, "U.S. External Deficit."

22. The index is a weighted average of eight major countries for which up-to-date data are available. The weights are determined by the share of the countries in the total trade (exports plus imports) of the group in 1980. The countries and weights are: Austria, 0.029; Canada, 0.091; France, 0.163; Germany, 0.254; Italy, 0.123; Japan, 0.089; Netherlands, 0.098 ; United Kingdom, 0.154 . 
Figure 1. The Dollar and the Real Interest Rate Differential, 1978:1-1988:6a

$1980=0$

Percent

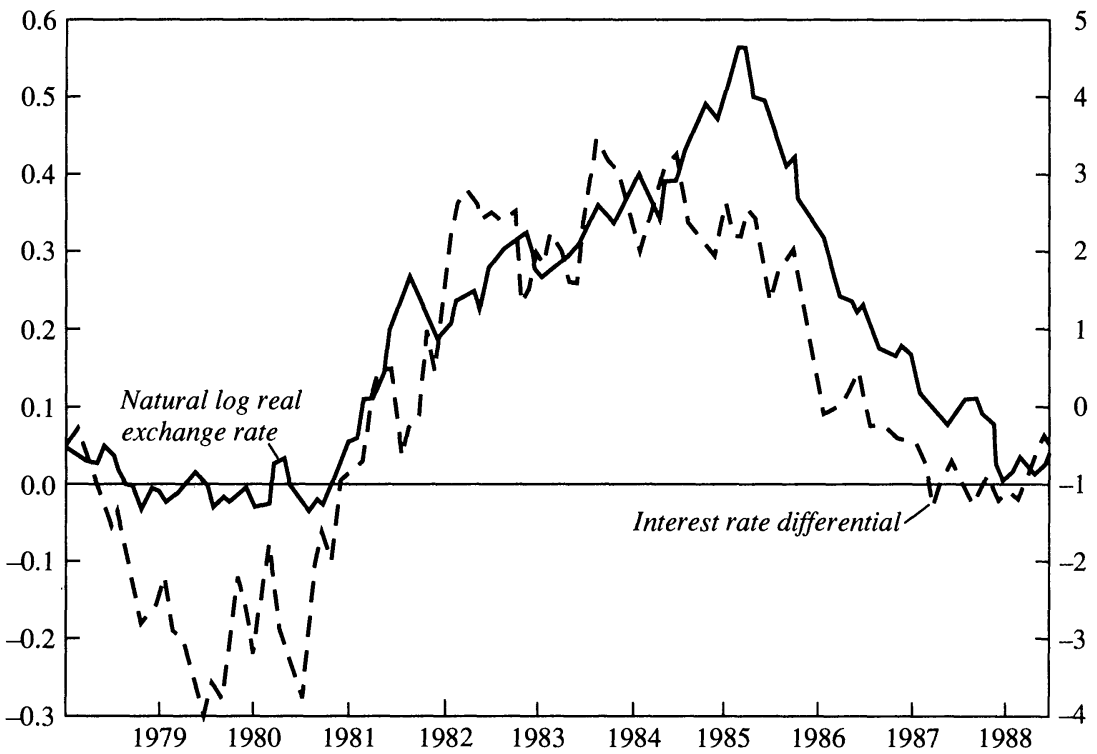

a. Real interest rates calculated as the long-term rate minus the CPI inflation rate of that month over the same month of the previous year. Differential measured between the United States and a weighted average of other countries.

previous year. The scaling of the diagram is such that each 1 percentage point interest rate differential corresponds to a 6.6 percent real exchange rate movement $(n=6.6){ }^{23}$ Clearly, the rise in the dollar between 1980 and early 1985 corresponds to a sharp increase in the real interest rate differential in favor of the United States, while the fall of the dollar corresponds to an elimination of the interest rate differential between 1985 and 1988.

The Feldstein-Marris contention that the fall of the dollar signifies a growing risk attached to U.S.-dollar-denominated securities can be readily incorporated in the model just described. Instead of assuming perfect asset substitutability, assume that a risk premium is necessary

23. This coefficient is based upon the following regression, for monthly data 1978:1 to 1988:6:

$$
\begin{gathered}
\log \left(P / E P^{*}\right)=\begin{array}{c}
-0.1688+0.066^{*}\left(r-r^{*}\right) \\
(22.55) \quad(19.83)
\end{array} \\
R^{2}=0.76 ; \text { Durbin-Watson }=0.24
\end{gathered}
$$


to induce foreigners to hold U.S.-dollar-denominated assets. Denote the risk premium per period by $d$. The interest arbitrage equation, equation 2 , becomes

$$
\left(x_{t+1}\right)^{e}=x_{t}+\left(r_{t}-r_{t}^{*}-d_{t}\right) .
$$

Summing over $n$ years as before, and denoting the average of the risk premiums between year $t$ and $t+n$ as $d_{n t}$, yields

$$
x_{t}=x^{c}-n\left(r_{n}^{e}-r_{n}^{* e}-d_{n t}\right) .
$$

Now, a rise in the risk premium requires either a depreciation of the dollar or a rise in the interest rate differential, or probably both.

The argument that the dollar is falling because of a rising $d_{n t}$ can be checked by asking whether the dollar has fallen more than would be implied by a falling interest rate differential. Indeed, if the United States were in a true hard landing, the interest rate differential should actually be rising as the dollar is falling. We can see from figure 1 that this has not been the case. At least through June 1988, there is little evidence that a rising risk premium on the dollar was an important factor in the decline of the dollar.

\section{Global Macroeconomic Repercussions of a Declining Dollar and Shrinking U.S. Trade Imbalance}

A common refrain of U.S. policymakers and many economists is that the declining dollar and shrinking U.S. trade deficit impose contractionary forces on the rest of the world economy. If the declining dollar reduces U.S. demand for imports and raises U.S. exports, the argument goes, domestic demand abroad will tend to decline, since foreigners will lose part of the U.S. market and at the same time will devote more of their demand to less expensive U.S. products. Therefore, policy abroad, and particularly fiscal policy abroad, should turn more expansionary to counteract the deflationary impulses coming from the United States.

This argument is certainly not correct as a general proposition, and even the sign of the effect of U.S. policies on output abroad is difficult to predict, for the reasons outlined below. J.-P. Fitoussi and E. S. Phelps, for example, argued in 1986 that the U.S. fiscal expansion was a major contractionary force in Europe and that a U.S. fiscal contraction would 
be an expansionary policy for Europe. ${ }^{24}$ The arguments that follow suggest that as the United States reduces its budget deficit, a sufficient action abroad to maintain demand would be mildly expansionary monetary policy. Indeed, it may actually turn out that the U.S. fiscal contraction is expansionary in its effect on foreign economies even with an unchanged path of the foreign money supply.

The effects of a falling dollar on growth in the rest of the world depend on the source of the dollar decline. If the dollar moved randomly without any link to economic fundamentals, then perhaps it would be possible to speak about the effects of an "exogenous" change in the exchange rate. As it is, we know that movements of the dollar are generally linked to movements in the interest rate differential, which are in turn linked to shifts in macroeconomic policy. Most of the rise in the dollar, at least until early 1984, followed the jump in U.S. real interest rates, which in turn resulted from the policy mix of loose fiscal and tight monetary policy. The decline in the dollar since 1985 is in turn tied to the partial reversal of that policy mix and the expectation of a further reduction of the deficit as a proportion of GNP, which has in turn lowered U.S. real interest rates relative to interest rates abroad.

The shifts in fiscal policy expectations, and in actual fiscal policy after 1985, are well known. The federal government budget deficit fell from a peak of 4.9 percent of GNP in 1985 to 4.8 percent in 1986, 3.4 percent in 1987, and a projected 3.1 percent in $1988 .{ }^{25}$ The decline to date, which is projected to continue under current legislation to a level of about 2 percent of GNP in 1992, should by itself account for an improvement in the current account balance of about $0.4 \times(4.9-3.1)=0.72$ percent of GNP, or roughly $\$ 34.9$ billion in $1988 . .^{26}$

It is less appreciated that at the same time that the fiscal shift began, the Federal Reserve Board began a sustained monetary expansion, in support of the policy of driving down the dollar. Table 7 shows the yearover-year rates of growth of reserve money and M1 on a quarterly basis between 1984 and 1987, the period of dollar depreciation. There is a clear shift toward easier monetary policy at the beginning of 1985, at the same time that the interest rate differential started to narrow. The high money

24. J.-P. Fitoussi and E. S. Phelps, "Causes of the 1980s Slump in Europe," BPEA, 2:1986, pp. 487-513.

25. See OECD Economic Outlook, no. 43 (June 1988), table 10, p.23.

26. See Congressional Budget Office, The Economic and Budget Outlook: Fiscal Years 1989-1993, table I-1, for forecasts of future budget deficits under current legislation. 
Table 7. Money Growth Rates, United States, 1984:1-1987:2

\begin{tabular}{ccc}
$\begin{array}{c}\text { Year } \\
\text { and } \\
\text { quarter }\end{array}$ & $\begin{array}{c}\text { Reserve } \\
\text { money }\end{array}$ & M1 \\
\hline $1984: 1$ & 4.0 & 8.4 \\
$1984: 2$ & 6.7 & 7.5 \\
$1984: 3$ & 6.0 & 6.2 \\
$1984: 4$ & 6.3 & 5.9 \\
$1985: 1$ & 8.5 & 6.7 \\
$1985: 2$ & 8.4 & 8.3 \\
$1985: 3$ & 8.9 & 11.3 \\
$1985: 4$ & 9.9 & 12.4 \\
$1986: 1$ & 9.6 & 11.8 \\
$1986: 2$ & 9.5 & 13.1 \\
$1986: 3$ & 10.5 & 13.4 \\
$1986: 4$ & 14.9 & 16.5 \\
$1987: 1$ & 11.6 & 15.5 \\
$1987: 2$ & 8.7 & 11.8 \\
\hline
\end{tabular}

Source: Author's calculations using IMF, International Financial Statistics, and updates from OECD Economic Outlook. Growth rates are quarter over same quarter of the previous year. Reserve money is defined by the IMF as the sum of currency in circulation, bank reserves, and demand deposits of the private sector with the monetary authorities.

growth continued until early 1987, when it began to slow. In response to this money growth, the economy expanded faster than the underlying steady-state growth rate, resulting in a fall in the unemployment rate between 1985 and 1988 of about 1.5 percentage points.

The McKibbin-Sachs simulation model can suggest the dollar exchange rate effects of the shift in the policy mix after 1985.27 Table 8 shows the effects of an announced stepwise reduction in government spending, to result in a stepwise reduction in the budget deficit along the lines of (but smaller than) the Balanced Budget and Emergency Deficit Control Act of 1985, better known as the Gramm-Rudman-Hollings act. As shown in the table, the budget deficit is credibly expected to improve by 3.8 percent of GNP in nearly equal steps over a five-year period. ${ }^{28}$

27. Warwick McKibbin and I are now preparing a more precise assessment of the effects of the policy mix, where we examine closely the change in budgetary expectations on a year-to-year basis during 1979-87.

28. In the simulation exercise, government spending on goods and services is cut each year by 0.8 percentage point of GNP. The change in the budget deficit is slightly less than the cut in spending because of an endogenous effect on interest rates and taxes. The overall size of the policy change is somewhat arbitrary (Gramm-Rudman-Hollings itself aimed for a larger correction of the deficit), but since the model is linear, the effects of a larger budget correction can be found simply by multiplying the numbers in table 8 by the proportionate increase in the experiment. 
Table 8. Cumulative Effects on United States, Japan, and Germany of a 3.8 Percent Reduction in the U.S. Fiscal Deficit over Five Years ${ }^{\mathrm{a}}$

Percent of GNP except where noted

\begin{tabular}{lrrrrr}
\hline & \multicolumn{5}{c}{ Cumulative effect } \\
\cline { 2 - 6 } Country & Year 1 & Year 2 & Year 3 & Year 4 & Year 5 \\
\hline United States & -0.4 & -0.5 & -0.5 & -0.5 & -0.2 \\
Output & 0.7 & 1.0 & 1.2 & 1.3 & 1.3 \\
Real trade balance & 0.6 & 1.1 & 1.4 & 1.8 & 1.9 \\
Inflation & -0.6 & -1.4 & -2.2 & -3.0 & -3.8 \\
Budget deficit & -3.3 & -3.7 & -4.2 & -4.5 & -4.8 \\
Long-term real interest rate & & & & & \\
Japan & 0.5 & 0.1 & 0.2 & 0.2 & 0.2 \\
Output & -0.6 & -0.9 & -1.1 & -1.3 & -1.4 \\
Real trade balance & 0.0 & 0.1 & -0.6 & -0.9 & -1.2 \\
Inflation & 10.0 & 15.0 & 18.1 & 20.2 & 20.5 \\
Real exchange rate & -3.1 & -3.3 & -3.6 & -3.8 & -4.0 \\
Long-term real interest rate & & & & & \\
Germany & 1.0 & 0.7 & 0.6 & 0.6 & 0.3 \\
Output & -1.1 & -1.5 & -1.7 & -1.7 & -1.6 \\
Real trade balance & 0.5 & -0.1 & -0.5 & -0.8 & -1.3 \\
Inflation & 10.9 & 14.8 & 17.3 & 18.4 & 17.6 \\
Real exchange rate & -2.9 & -3.1 & -3.4 & -3.7 & -3.9 \\
Long-term real interest rate &
\end{tabular}

Source: Simulation of the McKibbin-Sachs Global Model (2), version October 1988.

a. The policy is an anticipated stepwise cut in government spending of 0.8 percent of GNP per year over a period of five years (thus, an overall cut of 4.0 percent of GNP in government spending). Note that the effect on the budget deficit is slightly less than the size of the spending cut, because of induced effects on government tax collections that are built into the model. The money supply is adjusted each year to maintain full employment. Output and the real exchange rate are measured as a percentage change of their baseline values. The trade balance is measured as a change in percent of baseline GNP. The inflation rate and long-term real interest rate are the changes from baseline in percentage points per year. A positive value of the real exchange rate signifies a depreciation of the dollar relative to the yen or the Deutschemark.

The simulation exercise assumes that monetary policy accommodates the fiscal policy shift, with the money supply changing enough to keep the U.S. unemployment rate constant as the fiscal policy is tightened. The policy shift leads on impact to a real dollar depreciation against the yen of 10.0 percent, and real depreciation of about 18.1 percent by the third year. This depreciation results from the fall in U.S. interest rates relative to foreign interest rates on impact of the policy change.

The simulation also shows the likely trade balance effects of a sustained application of budget cuts, both on the United States and on the rest of the world. According to the simulation results, the five-year program of budget cutting reduces the U.S. trade deficit relative to baseline by about 1.2 percent of GNP by the third year, and by 1.3 
percent of GNP by the fifth year. ${ }^{29}$ The 3.8 percentage point phased reduction in fiscal deficits (from a level of some 4.8 percent of GNP in calendar year 1986) does not come close to eliminating the trade deficit, which starts at 3.4 percent of GNP in 1986.

The 1.3 percent of GNP reduction in the U.S. trade deficit by the fifth year is accommodated by a shrinkage in the Japanese surplus equal to 1.4 percent of Japanese GNP, and by a shrinkage in the German surplus on the order of 1.6 percent of German GNP.

The demand effects of such a policy mix on the rest of the world can also be examined. The surprising feature of these simulations, one that is contrary to much conventional wisdom, is that the shift in the U.S. policy mix toward fiscal contraction and monetary expansion imparts an expansionary impulse to the rest of the world, even though it causes the dollar to depreciate and causes U.S. net exports to rise. This result stands in contrast to Marris's warning, for example, that "Europe and Japan have not yet taken expansionary fiscal policy action on the scale necessary to offset the inevitable negative drag on their growth as the U.S. trade deficit is eliminated." 30

To understand the reason for the positive transmission effects, it is helpful to turn to the standard Mundell-Fleming model. ${ }^{31}$ The direction of international transmission of monetary and fiscal policy in the basic theoretical model is ambiguous. In a U.S. fiscal contraction, for example, the cut in the U.S. budget deficit leads to a dollar depreciation, a fall in U.S. output, and a reduction in world interest rates. The first two effects have a contractionary effect on economies other than the United States, as U.S. demand for exports from these economies falls, while the third effect (the decline in world interest rates) should have an expansionary effect by raising their consumption and investment. The net effect is therefore ambiguous, even though many commentators presume that a U.S. fiscal contraction must slow growth abroad.

29. In the October 1988 version of the McKibbin-Sachs model (2) reported in table 8, the effect of a deficit reduction on the trade balance is somewhat less than in the reported version of the model used in Roubini and Sachs, "Sources of Macroeconomic Imbalances in the World Economy," as reported in table 2.

30. See Stephen Marris, "Deficits and the Dollar Revisited" (Washington, D.C.: Institute for International Economics, August 1987), p. 39.

31. The model is described in Gillis Oudiz and Jeffrey Sachs, "Macroeconomic Policy Coordination among the Industrial Economies," BPEA, 1:1984, pp. 1-64; and in Michael Bruno and Jeffrey D. Sachs, Economics of Worldwide Stagflation (Harvard University Press, 1985). 
The overall sign of transmission depends on the reaction of foreign wages to the appreciation of the foreign currency vis-à-vis the dollar following the U.S. fiscal contraction. ${ }^{32}$ If foreign nominal wage growth slows down as the foreign currency appreciates, then it is more likely that the foreign economy will expand in reaction to the U.S. fiscal contraction. If the foreign nominal wage is perfectly rigid, on the other hand, then simple theory demonstrates that the foreign economy must contract in response to contractionary U.S. fiscal policy. The conventional wisdom is based on the simple model of fixed nominal wages. The McKibbin-Sachs simulation model, on the other hand, assumes a fairly high response in Europe and Japan of the nominal wage changes to consumer price changes, and therefore indirectly to exchange rate changes.

The theoretical ambiguity of the sign of international transmission is also true for monetary policy. A U.S. monetary expansion put in place alongside a contractionary fiscal policy has three effects: a dollar depreciation, a rise in U.S. output, and a fall in world interest rates. ${ }^{33}$ The first effect tends to reduce foreign aggregate demand by shifting overall demand from foreign goods to U.S. goods. The second and third effects tend to raise foreign demand. Once again, the overall effect depends on the foreign nominal wage response to the exchange rate appreciation of the foreign currency that is caused by the U.S. monetary expansion. With nominal wage rigidity abroad, the U.S. monetary expansion must cause a decline in foreign output. With high nominal wage flexibility, the U.S. monetary expansion will cause a rise in foreign output.

These simulation results undermine the presumption that a shift in the U.S. policy mix toward fiscal contraction and easier money will reduce foreign aggregate demand. The presumption is especially weakened in view of the substantial evidence of a rather close relationship between nominal wage change and consumer price changes in Europe and Japan. The simulation results cannot, of course, prove the case one way or another. Since it is naive to believe that one could actually get

32. Oudiz and Sachs, "Macroeconomic Policy Coordination."

33. In the simulation results, the fiscal policy contraction leads immediately to a reduction of long-term U.S. real interest rates by more than 3 percentage points. In Germany and Japan, the effect is 3.1 and 2.9 percentage point reductions, respectively. 
sound econometric estimates of the transmission effect, the sign and size of the transmission effects from the United States to the rest of the world must remain uncertain. ${ }^{34}$

The skepticism that the simulations generate about the conventional view, however, seems more realistic than the continuing "surprise" expressed in the past year about the vigorous growth in the European and Japanese economies despite the depreciating dollar. As predicted by the simulation model, Japan has experienced a domestic demand boom during 1987 and 1988 that has more than compensated for the negative growth effects of the declining real trade surplus. Similarly, in 1988 , Germany is now experiencing 3.5 percent to 4 percent annual growth for the first time in many years, based on domestic-led investment demand. Many forecasters had predicted German growth this year of 2 percent or under. ${ }^{35}$ It is notable that German unemployment continued to rise throughout 1982-84, when the Deutschemark was weak and exports to the United States were booming, and began to fall only after 1985 , with the advent of dollar depreciation and Deutschemark appreciation. ${ }^{36}$

34. If, in the end, expansionary measures are needed abroad to compensate for the shrinking U.S. fiscal deficit (that is, if the export effects abroad turn out to dominate the interest rate effects), there are good reasons to look for policies that can raise demand while preserving the tight fiscal policies in the European and Japanese economies. In a world of insufficient overall saving, and with a particular scarcity of capital for the developing world, growth measures that maintain saving are of particular value.

Three kinds of stimulative policies could be pursued that would also not restrict global saving. Most obviously, any slowdown in foreign demand could be counteracted by expansionary monetary policies abroad. Second, in view of the acute unemployment rates in the EC economies, combined with German hesitancy to expand money growth, there would seem to be a case for a significant depreciation of the non-Deutschemark currencies within the European Monetary System, combined with a monetary expansion in those countries. Third, rather than undertake direct fiscal expansion, Europe and Japan could increase the recycling of money to the cash-constrained debtor countries. The global expansionary effects of an increased dollar of loans to the problem debtor countries is roughly equivalent to a direct increase of a dollar of deficit financing.

35. In September 1987, the IMF predicted West German growth of 2.1 percent for 1988. In April 1988, the forecast was revised downward to 1.7 percent per year. In September 1988, the IMF projected 2.9 percent growth for the year. The main economic institutes of West Germany, as of October 1988, were forecasting around 3.5 percent per year. See "Budgets Built to Last," Economist (October 29, 1988), p. 76.

36. The German unemployment rates for the years 1982 to 1987 were: 6.7, 8.2, 8.2, 8.3, 8.0, 7.9. See OECD Economic Outlook, no. 43 (June 1988), p. 187, table R18. 


\section{The Present Risk to the U.S. Economy: Overheating, Not Hard Landing}

In my view, concerns about a hard landing for the U.S. economy are overstated. Over the next few years, risks probably fall more on the side of excessive inflation than on the side of a slump. In this final section, I outline two reasons for concern over inflationary prospects in the economy, both related to the depreciation of the dollar.

A significant part of the dollar depreciation since 1985 has been based on the expectation of a continuation of fiscal restraint along GrammRudman-Hollings lines. Since the dollar has returned in real terms to the values of the late 1970s, when both the current account and the federal budget were in virtual balance, the level of the real exchange rate is likely, in the intermediate run, to lead to excess demand in the U.S. economy if the current levels of budget deficits persist. The combination of rising net exports, induced by the weak dollar, and the strong internal demand, induced by the continuing budget deficit, will spill over into excess demand and rising inflation. If the budget deficit remains stuck in place, then the dollar would have to appreciate once again in real terms. That could happen through a reversal of the nominal depreciation of recent years, or through a rise in the domestic price level, holding fixed the nominal exchange rate.

The second inflationary risk could arise if the monetary authorities were to attempt to push the dollar still lower through expansionary monetary policy, in the vain attempt to reduce the external deficit through money-induced dollar depreciation. As already noted, monetary ease can raise exports and overall income if there is less than full employment, but it is not particularly effective in reducing a trade imbalance. Any attempt to target monetary policy on the external balance is bound to lead to frustration and inflationary pressures.

So far, the inflationary effects of the weaker dollar have been modest, for two unexpected reasons. First, the pass-through of the dollar depreciation into higher import prices of finished goods has been lower than usual, as foreign producers have "priced to market" more than usual. Second, the dollar price of oil has continued to plummet even as the dollar exchange rate has weakened significantly. (Most other primary 
commodities prices have risen along with the decline of the dollar, in line with historical experience.) These factors have so far restrained the inflationary effects of the dollar's decline, and it is only a gamble that they can be relied upon in the next few years to help maintain price stability. 


\section{Comments and Discussion}

Robert Z. Lawrence: As in a song currently near the top of the charts, the refrain in Jeffrey Sachs's paper is "Don't worry." In particular, don't worry about the rest of the world. Those of you who believe the United States should do nothing about the fiscal and trade deficits, don't worry-the world will finance it. Those of you who believe the United States should and perhaps- the optimists among you-will do something about the fiscal deficit, don't worry-U.S. budget cuts will not trigger world recession. Indeed, a fiscal contraction in the United States may actually be expansionary for the rest of the world. I should add that no one need worry about foreign willingness to finance the current account deficit.

I am sympathetic to the central message of the paper. Many who have been disappointed in the lack of U.S. fiscal discipline have forecast a crisis to spur greater action. In this vein the latest is the view that unless the next administration quickly takes a significant step toward reducing the deficit, we will see a crisis in the foreign exchange market, followed perhaps by a global recession. But the crash-landing forecasts have been notably inaccurate. The prediction was that a falling dollar would be associated with much higher U.S. inflation and interest rates, slow U.S. growth, and a slump abroad. In fact, since 1985 the dollar has indeed fallen-the decline has been of the order of magnitude predicted by Stephen Marris 1 -but it has been accompanied by lower U.S. interest rates, sustained U.S. growth, relatively low U.S. inflation, and a pickup in growth in Europe and (with a lag) in Japan. Now the critical reason

1. Stephen Marris, Deficits and the Dollar: The World Economy at Risk, Policy Analyses in International Economics 14 (Washington, D.C.: Institute for International Economics, 1985). 
for the differences between the crash-landing scenario and what has happened lies in the distinction between market-initiated and policyinitiated adjustment. The dollar's decline, as Sachs points out, has occurred not because of a stampede out of dollars but because of fundamental changes in policies. We have seen a shift toward easier monetary and tighter fiscal policy in the United States, and, I would add, a shift toward easier policies abroad. Indeed, OECD data show that Germany, the country we generally pick on as a growth laggard, increased its cyclically adjusted budget deficit by 0.3 percent of GDP in 1986 and 1987 , and is expected to add an additional 1.0 percent of stimulus in 1988.

I also agree with Sachs that the current path of fiscal and current account deficits appears to be sustainable for several years. As I see it, the U.S. current account deficit will be on the order of 2 percent of GDP-or around $\$ 110$ billion in 1989. Borrowing this amount for five years might add around three-quarters of a percent of GNP in permanently higher net foreign interest servicing but will not entail a solvency problem for the United States.

The current U.S. situation is in fact pernicious precisely because of the weakness of the constraints-both political and external. Simply because the situation is sustainable does not imply that it is desirable. The primary cause for concern is not the rest of the world pulling the plug but the slump in our national saving rate. While we may question the accuracy of our measures of the levels of national saving, the size of the real budget deficit, and the absolute magnitude of U.S. net indebtedness, no one disputes that there have been major declines in these variables in the $1980 \mathrm{~s}$. And yet, given the need to raise productivity growth and provide for the baby-boom generation's retirement, the United States should be saving more, not less, than its historic average.

The bottom line is that the United States looks creditworthy. A second consideration is foreign willingness to accumulate U.S. debt. In a world of imperfect substitutes, even creditworthy borrowers will have to pay higher rates to increase their borrowing. But Sachs points out that U.S. borrowing is a relatively small share of developed-country saving. $\mathrm{He}$ uses gross saving; I would use net. In that case the U.S. share is around 16 percent rather than 9.5 percent, but the borrowing still looks sustainable to me.

It is, however, important to remember that even net creditor countries 
can have sizable foreign exchange rate crises. Let me note some disquieting evidence that suggests such a crisis cannot be dismissed. First, Sachs argues that exchange rates can be readily explained by real interest rate differentials. But the fit is by no means perfect. There is a conspicuous divergence between actual and predicted exchange rates shown in his figure around the begining of 1985-a period many would argue was a bubble. And if we have had bubbles and irrational overshooting on the upside, we cannot rule it out on the downside.

Second, and in a similar vein, the market has been a biased and remarkably poor forecaster of exchange rates. Even those who think its judgment is the best we have must concede that it is not very good. I find it hard to find solace in the absence of a risk premium on U.S. debt. In 1981 , commenting on a paper in this journal on LDC debt, Sachs himself dismissed the possibility of a crisis, based on evidence that the market placed low risk premiums on LDC debt. ${ }^{2}$

Third, recall that in 1987 official financing played a major role in supporting the U.S. current account deficit-suggesting that without this assistance, market forces might have driven the dollar much lower because of impatience about the lack of improvement in the current account. Once the improvement became clear to the market this year, private confidence was restored. The argument made by those of the crash-landing school is that once the current U.S. improvement comes to an end, private market jitters will return. Indeed, implicitly, the absorption approach Sachs uses to forecast the current account implies even less improvement than do most conventional partial-equilibrium models.

Finally, the crash-landing school would say that the United States has been incredibly lucky, both in having excess capacity in the global economy and in having falling oil prices. Such good fortune cannot be counted on in the future.

A foreign exchange rate crisis cannot be ruled out. It is of course important to remember that a sharp decline in the dollar need not mean a crash landing for the real economy. While a further decline in the dollar may present problems for macroeconomic policy, it does not necessarily lead to a U.S. or global recession.

2. Discussion of Robert Solomon, "The Debt of Developing Countries: Another Look," BPEA, 2:1981, pp. 593-607. 
Ultimately the crash landing could come from two developments: first, a widespread perception the United States had entered a serious inflationary period (and was trying to renege on its debt), and, second, a sense that leadership in the United States was weak. Responsibility for avoiding the first possibility rests primarily with the Federal Reserve. A speedy response in U.S. interest rates that addresses the concern about inflation will, as we have seen over the past few months, induce foreigners to continue to lend. It will also, in the medium term, improve the current account by slowing U.S. growth. Responsibility for avoiding the second possibility rests with the president and Congress. They need to do more than communicate through lip-reading. The perception of a strong U.S. leadership would allow the United States to muddle through for a while, but divided leadership could make foreign investors very nervous.

Even if an exchange rate crisis were to erupt, the United States still has a major mechanism for procrastination-borrowing in foreign currencies. Foreigners sell dollar assets because of exchange rate and interest fears, not fears of U.S. insolvency. Foreign central banks, in particular, would probably accumulate Bush bonds for quite a while.

What about the danger of a foreign contraction if the United States actually does something about the deficit? I think Sachs has an important point about mechanisms that operate to stimulate foreign demand when the dollar falls. I would strengthen his point first by referring to the actual evidence on nominal wages over the past three years in the OECD. It looks as though nominal wages have fallen in every OECD country from 1985 to 1987 . But I think Sachs fails to give sufficient credit to the most important mechanism - the endogenous policy responses. We live today in a mixed system of both fixed and floating rates. And we know unambiguously that monetary policy shifts lead to synchronized fluctuations under fixed rates. When the United States has eased monetary policy over the past few years, foreigners have tended to lean against the wind, resisting the appreciation of their currencies and increasing their monetary growth. This effect has also been clearly evident in the reverse direction this year as U.S. tightening has led to dollar appreciation and foreign resistance by tightening monetary policy. This mechanism suggests that a falling dollar induced by additional fiscal contraction in the United States is likely to raise foreign money supplies endogenously as it did in 1986. Indeed one would hope this would be the response. I give credit to expansionary foreign monetary and fiscal 
policies over the past three years for avoiding a global slump and would expect similar responses in the future.

Sachs makes an interesting case that, because it stimulates U.S. domestic investment, eliminating the federal budget deficit will by itself not suffice to bring the current account into balance. He also suggests monetary policy can have little or no impact on the current account. If he is correct, foreign investment must grow more rapidly than foreign saving to aid the U.S. current account adjustment. It will be important to stimulate European capacity expansion and allow developing countries debt relief, so they can shift toward investment-led growth.

Let me conclude by stressing that the U.S. problem is not solvency but an inadequate provision for the future. The main reason to reduce the federal budget deficit is to raise U.S. national saving over the long run, not to avoid a foreign exchange rate crisis in the short run. We and the world should be fine as long as the initiative for deficit reduction is held by the United States. Should the United States lose that initiative, however, a market-imposed adjustment cannot be ruled out.

\section{General Discussion}

Sachs's simulations showing that a reduction of the U.S. fiscal deficit has an expansionary effect abroad drew considerable comment. George Perry asked Sachs to elaborate on the mechanism that generates this negative transmission of fiscal policy. According to Sachs, the result relies on the responsiveness of foreign nominal wages to the depreciation of the dollar coming from the U.S. fiscal contraction. Foreign nominal wages must fall relative to foreign prices in response to cheaper U.S. imports that lower foreign consumers' cost of living. Sachs argued that this reduction in foreign wages will result in foreign output greater than that in the simple Mundell-Fleming model where nominal wages are fixed and the transmission of fiscal policy is positive.

Ralph Bryant observed that this negative transmission result distinguished the McKibbin-Sachs Global Model (MSG2) from other empirical models of the international economy, noting that it differed from all the simulations in a 1986 comparison of models in which Sachs and McKibbin both participated. Bryant acknowledged that foreign monetary authorities might well respond to a fiscal contraction in the United States with a monetary expansion of their own. Through that policy response, a 
U.S. fiscal contraction could lead to an expansion of foreign output. However, he noted that the MSG2 simulations hold monetary policies fixed as the U.S. fiscal deficit is reduced. Peter Hooper noted that even in the 1986 simulations to which Bryant referred, several characteristics of the MSG2 model made it stand out from other models. By the very end of the simulation period the model predicted at worst a zero transmission of fiscal policy shocks. Furthermore, the model had an extreme, nearly one-for-one, response of foreign interest rates to U.S. rates. Other models displayed less than half as much decline in foreign interest rates in response to lower U.S. interest rates. Hooper noted that regardless of whether the MSG2 model is correct in its specification of foreign monetary reactions, Sachs's results suggest that the negative transmission effects of a U.S. fiscal contraction could be offset by a monetary expansion abroad.

Edmund Phelps believed Sachs's simulation results were plausible empirically as well as theoretically. He pointed to the pickup in the economies of Sweden, Britain, and Germany that had accompanied the reduction of the U.S. fiscal deficit without any major changes in these countries' own fiscal policies. Phelps went on to discuss simulations by John Taylor that showed the Fitoussi-Phelps expansionary effect of U.S. fiscal tightening on European output overtaking the Mundell-Fleming contractionary effect after about 10-12 quarters. Georges de Menil reported that, with a reasonable range of parameter values, simulations can yield ambiguous results on the transmission of fiscal policy, so there was no firm basis for predicting the effects on foreign output of U.S. fiscal contraction. But he added that the decline in world interest rates that would follow a reduction in the U.S. budget deficit is highly desirable.

Bradford De Long discussed the relation between the U.S. real exchange rate and the real interest rate differential. He observed that in Sachs's figure 1, the real exchange rate is now at about the 1979-80 level, but that the real interest rate differential is now about 3 percent higher than it was in 1979-80. De Long reasoned that either the equilibrium real exchange rate has fallen dramatically or, more plausibly, foreign investors now require a larger real interest rate differential in order to hold dollar assets. Peter Hooper agreed with the thrust of De Long's comment. He noted that, historically, a 1 percent change in the real interest rate differential has been associated with a 7 percent change in the real exchange rate. Since 1985, the real interest rate differential has fallen about 4 percentage points, thus accounting for a little more than half of 
the 55 percent fall in the real exchange rate. Hooper reasoned that the other half could be due to either of the two sources identified by De Long. However, Sachs noted that part of the fall in the real exchange rate should be seen as undoing the bubble that drove the value of the dollar about 20 percent too high in 1985.

James Duesenberry thought Sachs's focus on simplified models and simulations was too narrow. Clearly a hard landing will not be the most likely econometric forecast based on a reasonable range of policy choices. According to Duesenberry, the true risks come not from the steady-state accumulation of debt, but from exogenous events and contingencies that cannot be captured in a simple model. He advocated looking at the range of shocks, such as fears of inflation, fears of an adverse change in U.S. policy, or events elsewhere in the world, that might hit the economic system. For example, it is disturbing that substantial central bank intervention was required to support the dollar during 1987. He further advocated assessing the policy actions that governments will take in response to such shocks. The true risk lies in a situation where the authorities fail to pull themselves together to meet a crisis. Albert Wojnilower observed that a set of countries such as Japan, Korea, Mexico, and Thailand will, because of culture or outstanding debt, continue to produce more than they consume over the foreseeable future. Therefore, other industrialized countries should not engage in "beggar thy neighbor" policies in order to run current account surpluses. He saw the adoption of these negative sum policies by industrialized countries as an example of the type of risk emphasized by Duesenberry.

Benjamin Friedman discussed portfolio risks that might arise from the shrinking trade deficit. He observed that in certain markets for hard assets, such as real estate in major U.S. cities, foreigners have recently become essentially the only buyers. If the trade deficit is eliminated, this foreign demand for hard assets will dwindle, and prices for these hard assets might have to fall considerably before domestic investors are again attracted to buy. The fall in asset prices could have further repercussions if their domestic owners are highly leveraged. However, he added that it may be several years before this problem materializes because foreigner investors currently are holding a historically low proportion of their U.S. portfolios in the form of hard assets. Friedman predicted that foreign investors will continue to demand hard assets for a time as they attempt to balance their portfolios. 